\title{
historical fiction and the colonial violence in allegorical truth of the proposition \\ FELICITY COLLINS
}

\section{— Introduction}

On the eve of Australia Day 2006, Prime Minister John Howard used a short but much disputed part of his address to the National Press Club to berate postmodern approaches to historical truth:

Too often, [history] is taught without any sense of structured narrative, replaced by a fragmented stew of 'themes' and 'issues'. And too often, history, along with other subjects in the humanities, has succumbed to a postmodern culture of relativism where any objective record of achievement is questioned or repudiated. ${ }^{1}$

What the Prime Minister favours is 'balance' - a value located for him 'at the centre of the modern Australian achievement' which unites Indigenous and immigrant Australians into 'One People, One Destiny'.

At the time of the Prime Minister's speech Kate Grenville's historical novel, The Secret River (2005), and John Hillcoat's violent frontier film, The Proposition (2005), were generating arguments about the historical value, respectively, of realist novels and revisionist westerns dealing with the controversial issue of colonial violence between Indigenous and settler Australians. This article sifts through these debates, prompted by the defensive critical response of local historians to Grenville's novel, and by my first viewing of The Proposition-a viewing which left me with an unshakeable sense of the 'irrefutable truth' of frontier violence as a 'fact' of Australian history. But how can a fictional narrative tell an 'irrefutable' truth about the past? What kind of truth arises from allegory if not historical truth? Are historians 
right to reject 'allegorical' truths as myth because such truths 'corrupt' the 'consultable' historical record?

I begin with the gap between two discourses: the local controversy among historians over the truth status of historical fiction provoked by Grenville's Booker-nominated novel; and a long-running EuroAmerican argument about the representability of 'holocaustal events' a debate informed by realist, modernist and postmodern approaches to problems of historical reference in mass mediated societies. I argue that, in the gap between these discourses, The Proposition, as one of a recent cycle of Australian feature films about colonialism and its afterlife, constitutes an experiment with historical allegory rather than a postmodern 'stew'. This cycle of 'history films' began with One Night the Moon (Rachel Perkins, 2001), quickly followed by Rabbit-Proof Fence (Phillip Noyce, 2002), Black and White (Craig Lahiff, 2002) and The Tracker (Rolf de Heer, 2002), to be joined more recently by The Proposition and the 'precolonial' film, Ten Canoes (Rolf de Heer, 2006). Although conventional in form, these films are experimental in the sense identified by Meaghan Morris: they 'help create the possibility of a "field" of intersubjectivity where a different form of public memory may take shape'.2 However, it is precisely this possibility that most worries certain Australian historians.

\section{- Historical truth}

Australian historians involved in defending historiography against fiction have focused their attention on Grenville's casual treatment of history as a repository of stories which novelists 'pillage' and then 'wilfully and knowingly' get wrong. ${ }^{3}$ Remarkably, historians were not bothered by the staid, nineteenth-century realist form that resulted from this pillaging. Nor did they take issue with The Secret River's inexorable building of tension towards the 'inevitability' of a horrifying massacre as the 'truth' of the colonial frontier. What aroused the ire of historians was Grenville's claim that her novel could rise above the parochial squabbles of the history wars by getting 'inside the experience' of the past. ${ }^{4}$ This ire was particularly surprising in the case of Mark McKenna and Inga Clendinnen, two leading historians noted for the eloquent, reflective, literary quality of their respective books on the intimacy of colonial encounters between Indigenous and settler Australians. ${ }^{5}$

Both McKenna and Clendinnen took issue with Grenville for claiming that novels do a better job of taking us into the past than historians caught up in the history wars. Identifying a 'crisis of historical truth' and the 'loss of [the historian's] cultural authority' as the legacy of the history wars, McKenna claims:

At issue here is not ... the power of fiction to embody a profound historical understanding of the world, but ... the dangers that arise when novelists and reviewers of fiction claim for fiction, at the expense of history, the sole right to empathy and historical understanding. ${ }^{6}$ 
Clendinnen responded to both McKenna and Grenville by shifting the terms of the argument from 'historical understanding' to 'the moral implications of good history'. ${ }^{7}$ Much of her concern is to distinguish the moral purpose of history from the aesthetic purpose of the novel. After a thorough dissection of 'Applied Empathy' as Grenville's 'secret method' (20), Clendinnen acknowledges Grenville's careful historical research but concludes that, 'the "insights" of empathy are untestable', and more importantly, 'an unexamined confidence in empathy tempts us to deny the possibility of significant difference', so that those with whom we cannot empathise are identified 'as evil, or even as less than human' (27). Noting the ubiquity of 'opportunistic appropriations' of history, along with the erosion of memory, Clendinnen advocates a watchdog role for today's historian, bound by 'the iron rules of the discipline' (67):

Given the power of stories, historians must be on constant alert regarding their uses, because

... their obligation is to preserve the past in its least corrupted form. (65)

However, Clendinnen's aim is not only to protect the integrity of the past from those who would raid it for a good story. She also seeks to secure the moral authority of history as a discipline, 'based on the honest analysis of the vast, uneven, consultable record of human experience'. ${ }^{8}$ As a preface to the question, 'how can the historian's moral vision be manifested?' (55), Clendinnen turns to the burning issue in the history wars: present day responsibility for colonial violence and dispossession of Indigenous Australians. After exploring Howard's patriotic history (58) and John Hirst's 'strangely legalistic argument' (51), Clendinnen comes out in favour of an 'informed patriotism' (58) based not on 'a guided tour of the elevating bits of the nation's past', but on the 'investigation of conflicts between competing values and interests, always with a proper regard for clarity and justice of analysis and the relevance of evidence' (61-2). This rational, moral template is set against the novelist's contract with the reader: 'to delight' (31).

Historiography, in its rationalist mode, as Stuart Macintyre says, 'rests on a distinction between truth and myth'. ${ }^{9}$ It relegates historical fiction to entertainment and conflates entertaining fiction with the consoling category of myth. McKenna, for instance, equates 'patriotic allegory' with 'comfort history' and regrets the Anzac story, 'emptied of its historical context' being 'turned into a sacred parable, a hymn of national praise'. Other historians, however, are bothered by the sharpness of the line separating fiction, myth and stories from 'history'. They acknowledge that historiography involves precisely what Prime Minister Howard demands for Australian students: the narrative organisation of 'actual events' and 'identifiable human actors' into 'a coherent and instructive whole'. In a public conversation with Dipesh Chakrabarty on these issues, Bain Attwood raises the question of 'whether you can tell the truth about the Aboriginal past by using traditional methods of history'. ${ }^{10}$ He sees 
the way out of the impasse between historical fiction and truth as 'a dark path' involving 'a number of moves ... that historians have already started to make'. The first is 'to consider what memory and myth reveal retrospectively', while another is to take into account 'traumatic histories'-but, he cautions, these only 'take us so far in trying to resolve the impasse' (206). Chakrabarty responds that, in the end, 'one has to somehow risk the disorder [of a more inclusive, if less verifiable history] that could also be democracy' (207).

This national debate, pursued energetically by historians and the literati in Sydney and Melbourne, ignores the extensive work of cultural historians and critics engaged with cinema and television as the twentieth century's most powerful arbiters of historical understanding. As British historian Bill Schwarz points out, it is standard procedure for historians 'to raid social fictions — the novel, the film—for historical evidence', with 'no curiosity about the form in which the narrative itself is embedded. ${ }^{11}$ In promoting the moral vision of academic history over the aesthetic delights of historical fiction, Australian historians are in danger of corralling historical understanding for the profession. But, as American historian Robert A. Rosenstone asks, after two decades of defending 'history on film':

Why not just accept that a Cox or the others are already historians and take a look at how such film makers construct their histories-why not investigate their rules of engagement with the traces of the past, rules of engagement that come out of the possibilities and practices of the medium in which they work. ${ }^{12}$

But the issue goes deeper than Rosenstone's plea to historians 'to accept a new sort of history' based on different rules of engagement. ${ }^{13}$ As Geoffrey Nowell-Smith stated so succinctly in 1990, the 'daunting task' is not only to understand how cinema is 'embedded' in histories of economics and politics, but how cinema (and television) are embedded 'even more deeply into the history of modern subjectivity'. ${ }^{14}$ For Nowell-Smith, 'it is in these changing patterns of subjectivity, and their complex relationship to other patterns of historical change, that the story of cinema's effectivity lies. ${ }^{.15}$

In Australia, the history wars have prompted film and cultural critics to look at changing patterns of subjectivity in relation to colonial figures, particularly the tracker. ${ }^{16}$ Reviewing the cultural trope of the black tracker in relation to the history of the Native Police, anthropologist (and occasional screen actor) Marcia Langton addresses the relation between history, myth and new subjectivities. She begins by asking, 'How can we reconcile the mythology with the actual men on whom the fictional tracker characters were based? ${ }^{17}$ Rather than reject cinematic fictions for their myth-making, as historians have routinely done, Langton identifies an emerging pattern of subjectivity, arguing that 'new cinematic interpretations of the Aboriginal police tracker' and 'the readiness of the contemporary audience to encounter Aboriginal subjectivity and agency, along with complex accounts of the colonial past and 
postcolonial predicaments' may well 'provide us with some significant clues to the national zeitgeist'. ${ }^{18}$

\section{— Modernist truth}

For academic historians the archival document, corroborated by other forms of 'hard evidence', is the privileged source of historical truth. For such historians, realist historical fictions not only get the facts 'wrong', they involve Manichean structures of empathy and moral allegiance that undermine the complex truths of the written record. ${ }^{19}$ However, for avowedly modernist historians, the nineteenth-century mode of realist fiction is not so much a threat to historical truth as an inadequate means of representing what Hayden White calls the 'holocaustal' modernist event. ${ }^{20}$ For White, holocaustal events, which function 'exactly as infantile traumas [...] cannot be simply forgotten or put out of mind, but neither can they be adequately remembered' (20). The traumatic structure or 'modernist de-realisation' of such an event, and the difficulty it poses for those who inherit it and those who try to represent it, is said to lead either to the seductions of myth and melodrama (26) in popular genres, or to fantasies of 'intellectual mastery' in modernist narratives (32). Rejecting the modern electronic media's recorded images as manipulations which 'explode' the event (23), White concludes that,

anti-narrative non-stories produced by literary modernism offer the only prospect for adequate representations of the kinds of 'unnatural' events-including the Holocaust - that mark our era and distinguish it absolutely from all of the 'history' that has come before it.

Historians engaged with cinema have questioned White's claim that only modernist literary techniques have the potential to de-fetishise 'both events and fantasy accounts of them which deny the threat they pose' (32). Rosenstone, for instance, has become the champion of a postmodern canon of history films that, among other things, 'glory in their own selectivity' and make sense of past events 'in a partial and open-ended, rather than totalised, manner', making use of 'fragmentary and/or poetic knowledge'. ${ }^{21}$ But he goes further than creating a new, highly selective canon: he claims that the postmodern, self-reflexive history film, with its contradictory elements and multiple points of view, has much to teach historians, especially those social and cultural historians who recognise the need for a postmodern historiography but, so far, have failed to find a postmodern form. ${ }^{22}$

Although political modernism held sway among film theorists until the end of the 1980swith Eisenstein, Godard and Kluge as exemplary film-makers-by the 1990s the focus of the debate had shifted from history to memory as the site of 'authentic' engagement between subjectivity and the past. For Thomas Elsaesser, the shift from 'storytelling' to 're-telling, 
re-membering' is symptomatic of 'obsession, fantasy, trauma'. ${ }^{23}$ He connects this shift to the modern proliferation of traumatic events 'that neither narratives nor images seem able to encompass' (146). Arguing that there may be a limit to literary modernist/realist techniques of 'fracturing the viewer's identity' in order to make 'the extreme otherness of an historical experience representable' (174), Elsaesser suggests that a popular cinema of excess has the potential, as much as a modernist cinema of restraint, to elicit Betroffenheit-an affect which 'covers empathy and identification, but in an active, radical sense of being "stung into action"' (173).

In the Australian context—of a national, English-language cinema displaced from but aligned with both European art cinema and global Hollywood- the production of new, intersubjective, historical understandings does not turn on a formal choice between disciplined historiography, realist historical fiction, literary modernism or filmic postmodernism. Rather, the recent cycle of Australian history films is better understood in terms of the local specificities of media temporality in an import culture. From an international perspective, the cycle belongs to a temporality marked by the resurgence of historical allegory in national cinemas during moments of crisis or controversy.

\section{- Media temporality}

Taking up the problem of historical time in mass-mediated societies, Schwarz borrows a wellknown proposition from Fernand Braudel, the French historian who aimed 'to show that time moves at different speeds' (100). Braudel identified three kinds of historical time: the glacial temporality of geographical or environmental time; the social temporality of civilisations and their political and economic systems; and the ephemeral temporality of events which, in Schwarz's words, seemed to Braudel too 'fickle and intangible to be deemed historical' (101-2). As historians of modernity have pointed out, media time is not only fickleit is repetitive, obsessive and non-linear, aligned with subjectivity and memory rather than with history's objective, linear, rational ordering of time. Schwarz suggests that one of the ways we might understand the 'modern co-ordinates' of media time is through John Ellis's idea of television as a 'chat' arena for 'working-through' events, 'a process whereby material is not so much processed into a finished product as continually worried over until it is exhausted'. ${ }^{24}$ Rather than produce a plausible simulacrum of the past based on 'consultable' historical evidence, media temporality produces something akin to corruptible memory. For Schwarz, it involves 'misremembering, misinterpreting, the continual collapsing of narratives, narratives located in "the wrong" place, strange displacements, the merging of stories, repetitions' (105). Just as efforts to protect the consultable record of the past from the 'applied empathy' of the present have come under pressure from new types of sources, new kinds of events and new social subjects, the line drawn between historical time and media time 
has become harder to hold because historical reality itself is now thoroughly suffused by media reality. The problem that arises, then, is not so much one of whether this modern temporality is best represented in realist, modernist or postmodern forms, but of the 'derealised' status not only of the event, but of the subject and of representation itself.

An exemplary instance of the problem of derealisation is cinema's capacity to fake 'authenticity' through technological, stylistic and narrative techniques of composing and manipulating image and sound. But rather than debate the problem of 'authentic' historical representation, Elsaesser identifies a more pertinent issue: for him, the postmodern impossibility of adequately representing, remembering or working-through 'holocaustal' events or 'traumatic' histories is caught up with a new 'traumatic' formation of the subject, 'as the symptom without a cause, as the event without a trace'. ${ }^{25}$ He asks whether the media's obsessive, repetitive working-through of shocking historical events to the point of exhaustion might be better understood as 'a particular contemporary subject-effect' in which the subject's relation to history and memory 'is necessarily traumatic (because lacunary, incomplete, narratively no longer sanctioned)'. ${ }^{26}$

\section{- Historical allegory}

It is here, in the necessarily lacunary relation of the subject to history and memory, that the fragmented, incomplete, dialectical structure of allegory becomes relevant for understanding historical fiction as a potential antidote to, rather than instance of, myth-making. It is no coincidence that the dispute between historical truth and postmodern relativism in Australia returns obsessively to the 'traumatic scene', or 'holocaustal event', of frontier violence between indigenous and settler Australians. What is at stake, in Australia as elsewhere, is the necessity of remembering and 'mourning' or 'working through' a contested past-in ways that acknowledge what Judith Butler calls the 'unmourned losses' or 'ungrievable lives' of the defeated, of those written out of nation-building histories. ${ }^{27}$ Scenes of frontier violence conjured by historians, novelists, filmmakers and critics for different purposes, have transformed the postcolonial myth of terra nullius (an 'event without a trace') into a violent primal scene-the afterlife of which is now redefining the nation's origin and identity.

In his essay on postmodern mourning-work, Elsaesser suggests in passing that the traumatic structure of the 'holocaustal' event (which by definition eludes adequate representation and mourning) involves 'a crisis of perception ... that [requires us to] take in Benjamin's reflections on perception and shock, with allegory as the preferred hermeneutics of the shock experience'. ${ }^{28}$ I want to take up this neglected insight by looking, first, at Walter Benjamin's defence of allegorical expression as an antidote to myth and, then, at how iconographic scenes of colonial violence are 're-touched' by the allegorical intention in The Proposition. 
Benjamin's concept of Baroque allegory—as an instructive mode of emblematic expression which offers a new understanding of historical temporality—has had limited influence on historians. However, for cultural theorists, Benjamin's allegorical mode of understanding the origin (or ur-history) of the present through cultural debris, fossils or ruins, has opened up the idea of history as a fragmented, discontinuous (rather than grand) narrative. ${ }^{29}$ Benjamin's recognition of Baroque allegory's secular teleology_as a 'progression of moments' in a theatre of death, decline and decay emblematised by the skull or 'death's head'-derived initially from his study of the seventeenth-century German Trauerspiel or mourning-play. ${ }^{30}$ In the Trauerspiel the transience of nature expresses the transience of history. In Baroque allegory, historical transience finds its physical expression in the emblem of the ruin: 'In the ruin history has physically merged into the setting. And in this guise history does not assume the form of the process of eternal life so much as that of irresistible decay.'31

The allegorical image of history as ruin was developed further in Benjamin's extensive critique of the origins of modernity, manifest in the commodity economy of nineteenthcentury Paris. The Baroque ruin, as the emblem of natural decay, makes a violent, even destructive, return in the 'refunctioning of allegory' in Baudelaire's poetry: 'Baudelaire's allegory bears, in contradistinction to that of the Baroque, traces of a wrath which was at such a pitch as to break into this world and to leave its harmonious structures in ruins'. ${ }^{32}$ Here, allegory 'attaches itself to the rubble' and 'offers the image of transfixed unrest' as an image of historical time (38). For Benjamin, as for Baudelaire, 'myth was the easy path'Benjamin aimed to demonstrate 'the antidote to myth in allegory' (46). The myth that preoccupied Benjamin's allegorical thinking was that of history as progress. ${ }^{33}$ As an antidote, he offered the counter-image of history as catastrophe: "That things "just go on" is the catastrophe ... Redemption looks to the small fissure in the ongoing catastrophe' (50).

More recently, Benjamin's allegorical critique of history as progress has informed the study of Latin-American and Third Cinema, ${ }^{34}$ as well as feminist research into histories of film spectatorship, ${ }^{35}$ but, overall, allegory remains a marginal category in the reception of routine (rather than modernist or postmodern) history films. ${ }^{36}$ The suppression of allegory (as an inferior and antiquated form of didactic expression) by nineteenth-century modernism, and its return in postmodern art, was noted in 1980 by Craig Owens. ${ }^{37}$ Owens locates the postmodern allegorical impulse in the desire and 'capacity to rescue from historical oblivion that which threatens to disappear' (52-3). He writes:

throughout its history it [allegory] has functioned in the gap between a present and a past which, without allegorical reinterpretation, might have remained foreclosed. A conviction of the remoteness of the past, and a desire to redeem it for the present-these are its two most fundamental impulses. (53) 
Owens argues that allegory is not a hermeneutics but a way of seeing. It is a structure of perception that involves the doubling of one text by another, the reading of one text through another, 'however fragmentary, intermittent, or chaotic their relationship might be' (54). The allegorist 'adds another meaning to the image ... the allegorical meaning ... is a supplement' (54).

Allegory as fragmentary supplement to earlier texts is more like a postmodern 'stew' than a cohesive narrative, corrupting rather than preserving the 'original' meaning of the historical document. The allegorist revives stories, tropes and figures from outdated iconographies, adding another meaning, but, as Ismail Xavier argues, calculated allegories (for instance, the calculated parable of reconciliation in The Tracker) risk failure: the moral parable's easy access to 'truth' exploits allegory's totalising impulse, overriding its modern sensibility of incompleteness, a sensibility that is 'mindful of the gap between signifier and signified, intention and interpretation, a past which must be read and a present which must read the past'. ${ }^{38}$ For Xavier, the modern emphasis on allegory, 'as fragmented and incomplete discourse', challenges the totalising and teleological impulse of historical temporality (deployed, for instance, by Prime Minister Howard when he called for a cohesive, unifying history of 'One People, One Destiny'). Modern national allegory is 'a sign of a new consciousness of history' (349), where analogies between past and present do not confirm continuity and identity through authenticity and empathy. Rather, allegory doubles, supplements or reinterprets earlier texts in such a way that 'old facts, like old signs, lose their "original" meaning when looked at from a new perspective' (349).

Although Fredric Jameson notoriously relegated modern allegory to 'Thirdworldish' fictions of underdevelopment, ${ }^{39}$ Xavier makes a strong counter-argument that national cinemas, whether First or 'Thirdworldish', generate historical allegories in moments of crisis or controversy when the very categories of nation and identity are in dispute. Xavier rejects the idea that allegory is a premodern form, dispensed with by rationality and its preferred aesthetic of realism and naturalism. Rather, modern allegory 'expresses the historicity of human experience and value' because it conceives of historical time as change, as crisis, as breaks with the irretrievable past (341). Modern, national allegory, then, is better understood through Benjamin's counter-image of historical time as destruction rather than progress, as 'one single catastrophe which keeps piling wreckage upon wreckage'. ${ }^{40}$ But, of course, repression, violence and the shock of catastrophic events can easily be subsumed into new national myths. Such myths readily produce 'Firstworldish' allegories of progress, expansion and redemption-evident, for instance, in the teleology of Manifest Destiny that underpins classical Hollywood westerns. However, historical allegory in national cinema does not always affirm national mythology, as the constellation of allegories of underdevelopment in 'Thirdworldish' cinema in Brazil demonstrated in the 1960s: 'Tropicalist collage showed an inventory 
of the losers' history, foregrounding the crisis of the subject in the contemporary world and, especially, the death of two historical subjects: that of the proletariat amid mass culture and that of the nation amid globalization'. ${ }^{41}$ But what of historical allegory in a 'Secondworldish' cinema at a moment of national conflict? It is possible to argue that, in the recent constellation of films that re-figure the ongoing catastrophe of indigenous-settler relations in Australia, historical allegory is performing the paradoxical feat of aligning history's victors with the point-of-view of the defeated, producing a new, ethical form of subjectivity with a bicultural sense of 'nationhood' as one among several horizons of identity.

\section{- A revisionist eVEnt}

Although The Proposition was released at the same time as The Secret River, as a non-literary text noted for its violence and excess it fell beneath the radar of historians. ${ }^{42}$ But film reviewers had no compunction in claiming Hillcoat's frontier saga of retributive violence as a history film. For many, the film was a revisionist 'event' in national media temporality. Michael Fitzgerald claimed that, 'the western is boldly reinvented in an Australian light. One of the film's most revisionist touches is the depiction of the Aboriginal trackers'. ${ }^{43}$ But this specific 'event' in Australian media temporality was invisible to BBC Radio 4's reviewer who described the film as 'a bushranger Western ... set in a violent 1880s Australian outback exposing the bitter racial tensions between English and Irish settlers'. ${ }^{44}$ Others, however, saw the film as a truthful revision of the nation's history. A UK reviewer declared that 'Australia's brutal post-colonial history is stripped of all the lies in a bloody clash of cultures between the British police, the Irish bushrangers and the Aborigines'. ${ }^{45}$ An Australian reviewer predicted that, 'only those with a strong disposition will be able to stomach scenes of throat-cutting, torture, rape and exploding heads', but concludes that, 'The Proposition could be the most accurate look at our national history yet'. ${ }^{46}$

These are precisely the sorts of claims that have so irritated Australian historians who see the promotion of historical fiction as part of a worrying turn to what McKenna calls 'comfort history' or 'sacred parable'. But film critics were also quick to point to The Proposition's 'historical inaccuracies'. Carol Hart saw its lack of 'authenticity' on indigenous issues and its stomach-churning violence as fatal flaws, going so far as to claim that the outback landscape is 'the transcendent image that not so much allows the film to reveal itself, but rather serves to redeem it'. ${ }^{47}$ William D. Routt, however, champions the film's violence, seeing it as a source of non-redemptive transcendence or revelation. ${ }^{48}$ But where some see historical inaccuracy and myth, I see allegorical tropes as antidotes to myth; where Routt sees 'an art film about violence', I see allegorical supplements to an archival iconography of colonial scenes; and where others see transcendence (redemptive or not), I see a newly emerging subjectivity with a postcolonial, bicultural sense of the nation's past as one of its horizons. 


\section{- Allegorical time}

Understood allegorically, The Proposition takes its place among other texts that attempt to displace the nation's myth of origin from the sacred trenches of Gallipoli to the 'immense, historical crime scene' of the colonial frontier. ${ }^{49}$ By drawing heavily on the Baroque emblem of the ruin, The Proposition offers a 'theatre of death', a landscape of destruction, a temporality of 'transfixed unrest' as the nation's founding crime scene. When Captain Stanley (Ray Winstone) surveys this desolate landscape after the violent, opening shoot-out, he asks the allegorical question, 'Australia_what fresh hell is this?' From this moment, the film sets out to demolish the myth of colonial history as 'civilising progress'. In the name of progress, Stanley unleashes what is best described as a hellish circle of retributive violence. From the outset, it is clear that Stanley's civilising mission will pile one catastrophic event upon another. Recoiling from this unremitting theatre of destruction, many reviewers looked for some kind of redemption-for 'the small fissure in the ongoing catastrophe'. But taking a non-redemptive view of the film's violence, Routt claims that camera distance-from things too terrible to look at - is the key to the film's revelation of the Australian landscape as 'a primal scene of annihilation' (8). Rejecting the consensus that the film is a bushrangerwestern, Routt turns to Vachel Lindsay, an early film theorist who defined three kinds of films on the basis of camera distance: 'splendour' films defined by the long shot; 'action' films defined by the middle-distance shot; and 'intimacy' films defined by the close-up. In Routt's view The Proposition, with its overwhelming use of the close-up, is an intimacy film, 'about faces and souls', that shows us 'what violence does' (8).

The capacity of camera distance to 'reveal a new sense of the world' (8) bears on the question that interests me here, that of cinema's allegorical expression of historical time in images. As The Proposition's infamous flogging scene makes clear-through its framing of the afterlife of violence in shots of faces, bodies and the landscape-violence is a matter of more than one temporality, one horizon, one kind of camera distance. The film's repetition of scenes of violence to the point of exhaustion, ruin and decay, typical of Baroque allegory, accords with the repetitive temporality of modern media which exhausts rather than works through 'events'. As Benjamin says, allegory can be used against myth if, like Baudelaire's poetry, 'it bears traces of violence... necessary in order to rip away the harmonious façade of the world'. ${ }^{50}$ The specific national myth that The Proposition does away with through allegorical violence is precisely the landscape myth that literary critics try to redeem-a longstanding myth of Australia as a place where the transcendent image of the landscape redeems a melancholy settler history of incompetence and failure in a harsh new world. ${ }^{51}$ One of the ways The Proposition deconstructs this landscape myth is by bringing the intimacyimage of the face into direct contact with both the splendour-image of the landscape and the 
action-image of violence. When Hart and Flanagan fail to recognise these different temporal horizons within the film, opting instead for the splendour of the landscape to 'redeem' the film's violence, they settle for myth. Such readings miss the potential that screen violence has for a 'weak' redemption of the past in fleeting moments of recognition. ${ }^{52}$ They also miss the allegorical way in which the emblematic flogging scene is displaced from the penal colony to the frontier, an allegorical move that brings new meaning to an iconography of violence lodged in the Australian social imaginary as a residue of the British convict system. ${ }^{53}$

\section{- Allegorical supplements}

The Proposition supplements the iconography of convict flogging, giving it an additional, intimate meaning by bringing the anonymous faces of the crowd into close-up so that the viewer is implicated, not only in the crowd's appetite for violence, but in the moments of being sickened by it and gradually turning away from it. A further allegorical supplement comes from the soundtrack. As we watch the flogging we hear on the soundtrack, from another diegetic space, the 'angelic' voice of a rapacious boy singing an Irish love ballad which he reprises while he brutally assaults Captain Stanley's wife at the end of the film. With such juxtapositions, the film offers a temporal experience of violence, doubled and split along the horizontal axis of narrative continuity and the discontinuous vertical axis of sound and image.

As Xavier reminds us, in allegory these two axes present different possibilities for reinterpretation of earlier texts. Allegorical interpretation must take into account 'what is suggested by the horizontal succession of shots and by the vertical effects of visual compositions or cultural codes embedded on its soundtrack' (337). As Benjamin says of Baroque allegory, 'The high point is reached in the interludes, with their personified attributes, incarnations of the virtues and vices, without in any way being confined to them'. ${ }^{54}$ The vertical axis of The Proposition consists of allegorical compositions of ghostly landscapes, scenes of poetry and violence, and fragments of song and snatches of sound which serve as interludes. In these 'explanatory interludes' the different temporal horizons of the splendour shot, the action shot and the intimacy shot find aural equivalents: in the eternal or sacred horizon of the traditional hymn 'Happy Land'; in the dissonant social horizon of the 'Proposition' theme; and in the ephemeral, intimate motifs of 'Gun Thing', 'Moan Thing' and 'Sad Violin Thing'. Further, in The Proposition we find both axes on the soundtrack: the vertical axis of repetition in the insistent electronic drone and neutral open chords which don't progress but mingle with the chiming of clocks, screeching of cockatoos and buzzing of flies; and the horizontal axis of narrative progression in the emblematic 'Rider' song. In aural interludes throughout the film we hear intimate snatches of this song — an allegorical conversation between personified Nature and Violence-sometimes whispered, sometimes half-sung, 
sometimes reprised for a few bars, but finally sung and heard all the way through as the film ends, re-telling the film's story as allegory, re-membering the figurative truth of history as a circle of violence broken only when the rider 'lays down his gun'. ${ }^{55}$

Rather than tell the truth about Australia's colonial past, as many reviewers claim, or denarrativise historical truth as modernists prescribe, The Proposition adopts the guise of a revisionist western-bushranger-art film in order to supplement an existing media iconography of colonial times. ${ }^{56}$ As Ismail suggests, 'allegory is not simply produced by a storytelling process ... but also results from visual compositions that, in many cases, establish a clear dialogue with particular iconographical traditions, ancient and modern' (337). The film's allegorical intention is unmistakable in the opening and closing credit sequences which feature black and white archival photographs of indigenous and settler Australians in frontier settings. Hart claims that these archival photographs 'become mere signs bereft of a referent', concluding that 'authenticity in relation to the depiction of indigenous issues remains lacking. ${ }^{57}$ But from an allegorical perspective, these photographs are not, as Hart claims, 'signs without a referent'-they are culturally readable, iconographic scenes that are allegorically refigured and supplemented by The Proposition in a way that preserves their integrity but refuses to endow them with 'authenticity'. Rather than verify the film's diegetic scenes of frontier violence, the archival photographs correspond to scenes of violence in the film, fulfilling the structural requirement that allegory imposes 'a vertical ... reading of correspondences upon a horizontal chain of events'. These correspondences can be thought of in terms of the allegorical recovery of lost historical time in contemporary media time. Indeed, this is literally what happens to the archival photographs in the opening credits. They are clearly marked as archival documents, but, if we look closely, we might recognise the film's actors making an appearance in some of the photographs, literally re-covering the image for a new, media temporality.

As Benjamin declares, 'That which is touched [Betroffen] by the allegorical intention ... is simultaneously shattered and conserved'. ${ }^{58}$ Although the final montage of photographs at the end of the film does not dissolve the actors' faces into the photographs, here, too, we find the allegorical touch. This montage of photographs of 'routine' colonial violence includes the familiar image of Aboriginal men in neck chains-often interrogated by white members of the native police accompanied by black trackers. We see an interpretation of this iconography earlier in The Proposition when five tribal men, shackled together in neck chains, are brought in for questioning. David Gulpilil, again cast in the role of the black tracker, acts as their interpreter. But this routine scene does not end in further violence (or its moral condemnation) as we might expect. Rather, the iconographic image is conserved but also shattered by laughter. This laughter occurs at the expense of the white captain who realises that the Dogman joke, shared by the black tracker and the Aboriginal men in neck chains, 
is on him. ${ }^{59}$ In the end credit sequence, when we are shown, belatedly, an archival photograph of row-upon-row of Aboriginal men in neck chains, the film's allegorical practice of supplementing colonial iconography with an additional meaning is confirmed. At no point does The Proposition pretend to tell the story or reveal the history 'behind' the photographs. Rather, the film adds new, supplementary meanings to the cultural iconography of colonial violence to which the archival photographs belong. When Flanagan questions the historical 'authenticity' of the Dogman joke, he misses the point (made above with reference to Langton, Morris and Elsaesser) that cinema has the potential to produce new historical subjectivities-I would add, in just such moments. ${ }^{60}$

There is a further sense in which scenes of frontier violence in The Proposition can be considered allegorical supplements to histories of native policing in colonial times. If we read the film in terms of its much publicised, heat-crazed shoot in the flyblown town of Winton in Queensland, one of the intertexts available to us is Ross Gibson's lucid essay on the career of Frederick Wheeler, an officer of the Native Mounted Police Corps in central Queensland from 1856 to $1876 .{ }^{61}$ The actions of the native police on the Queensland frontier were described at the time as 'atrocities which ... will damn the character of the colony to all succeeding ages'. ${ }^{62}$ In this light, the film's narrative axis of Captain Stanley's blood-stained failure to 'civilise this land', doubles or supplements, but does not represent, adapt or translate, Gibson's brooding account of 'the sinister glamour' of Wheeler's career. Yet correspondences in tone, mood and vision between the two texts resonate in such a way that each 'verifies' the other. Together, the texts work as dis-placements and re-memberings, in media temporality, of traumatic, unrepresentable, unmourned historical events-though neither counts, among historians, as 'authoritative history'.

\section{— Conclusion: An emerging SUbJECtivity}

As allegorical reinterpretation, The Proposition supplements historical 'traces', rather than represents 'holocaustal' events. The question remains, under what conditions might a national cinema's allegorical reworking of colonial documents and popular frontier iconography into 'scenes' of violence, 'sting' viewers into an affective and ethical response? When we look at this current cycle of history films we might remember that scenes of colonial violence have been present in Australian film and television throughout the twentieth century. We might also remember that although frontier violence was well documented and debated with Whitehall during the nineteenth century, it failed to appear in national histories written after Federation in 1901. ${ }^{63}$ Such temporal 'gaps' in historical memory and media memory create 'small fissures' for the allegorical impulse 'to rescue from historical oblivion that which threatens to disappear'. But the recent cycle of films set in colonial times can also be understood as a response to another 'gap' in national history-the dismissal of the 
Reconciliation movement by the Howard Government in favour of a retributive 'war on terror' in Iraq, literally dis-placing the nation's colonial 'theatre of death' from public memory. This ethical failure (in Butler's sense) ${ }^{64}$ at the national level of Australian politics is emblematic of the defeat of whatever was emancipatory in the 'black armband' politics of the land rights movement of the 1970s, and the Stolen Generations report and native title legislation of the 1990s. But allegorical 'rescue' is not a matter of redeeming the past for new national myths, as The Proposition demonstrates. It is a matter of using allegory against myth to realise a different history, one that might recognise the potential of a 'Secondworldish' subjectivityat home with defeat- to transform national identity into something other than a 'sacred parable' built on the hellish repetition of violence and catastrophe.

FELICITY COLLINS is coordinator of the Cinema Studies Program at La Trobe University and coauthor with Therese Davis of Australian Cinema After Mabo (2004). Current research includes an ARC Discovery Project on Australian screen comedy and a project on the transnational charisma of screen actors David Gulpilil and Russell Crowe.<f.collins@latrobe.edu.au>

1. John Howard, Address to the National Press Club, Parliament House, Canberra, 25 January 2006, <http://www.pm.gov.au/news/speeches/ speech 1754 .html>.

2. Meaghan Morris, 'Beyond Assimilation: Aboriginality, Media History and Public Memory', Rouge, no. 3, 2004, <http:www.rouge.com.au/3/ beyond.html>. Morris is writing about the 'enabling tradition' that made Tracey Moffatt's work possible, particularly her experimental short film Night Cries (1989).

3. Kate Grenville, 'The Novelist as Barbarian', presented at the Challenging Australian History: Discovering New Narratives seminar at National Library, Canberra, 14-15 April 2000, <http://www.nla.gov.au/events/history/papers/ Kate_Grenville\%20.html>

4. Kate Grenville, interview with Ramona Koval, Books and Writing, ABC Radio National, 8 January 2006, <http://www.abc.net.au/rn/arts/bwriting/ stories/s1527708.htm>

5. Mark McKenna, Looking for Blackfella's Point, University of NSW Press, Sydney, 2002; Inga Clendinnen, Dancing with Strangers, Text Publishing, Melbourne, 2003.

6. Mark McKenna, Writing the Past: History, Literature and the Public Sphere in Australia, public lecture at Griffith Graduate Studies,
Queensland College of Art, Brisbane, 1 December 2005, <http://humanitieswritingproject.net.au/ mckenna.htm $>$. Further references are included within the text.

7. Inga Clendinnen, 'The History Question: Who

Owns the Past?', Quarterly Essay, no. 23, 2006, p. 47. Further references are included within the text.

8. Clendinnen, Dancing, p. 287.

9. Stuart Mcintyre, 'Politics and the Philosophy of History', Australian Historical Studies, no. 123, 2004, p. 132.

10. Bain Attwood and Dipesh Chakrabarty, in 'Conversation about Aboriginal Pasts, Democracy and the Discipline of History', Meanjin, vol. 65, no. 1, 2006, p. 206. Further references are included within the text.

11. Bill Schwarz, 'Media Times/Historical Times', Screen, vol. 45, no. 2, 2004, pp. 93-4. Further references are included within the text.

12. Robert A. Rosenstone, History on Film, Film on History, Pearson Education, Harlow, UK, 2006, p. 159.

13. Rosenstone, History on Film, p. 159

14. Geoffrey Nowell-Smith, 'On History and the Cinema', Screen, vol. 31, no. 2, 1990, p. 160.

15. Nowell-Smith, p. 171. 
16. See Felicity Collins and Therese Davis, 'Disputing History, Remembering Country in The Tracker and Rabbit-Proof Fence', Australian Historical Studies, vol. 37 , no. 128,2006 , pp. 35-54

17. Marcia Langton, 'Out From the Shadows', Meanjin, vol. 65, no. 1, 2006, p. 56

18. Langton, p. 64

19. See Murray Smith, Engaging Characters: Fiction, Emotion, and the Cinema, Clarendon Press, Oxford, 1995, pp. 73-106, on how structures of sympathy and empathy do not necessarily result in Manichean identifications but 'plural engagements' more complex than Clendinnen's critique of 'Applied Empathy' would allow.

20. Hayden White, 'The Modernist Event', in Vivian Sobchak (ed.), The Persistence of History: Cinema, Television and the Modern Event, New York, Routledge, 1996, p. 20. Further references are included within the text.

21. Robert A. Rosenstone, 'The Future of the Past: Film and the Beginnings of Postmodern History', in Sobchak (ed.), The Persistence of History, p. 206

22. Rosenstone, 'The Future of the Past', pp. 205-6.

23. Thomas Elsaesser, 'Subject Positions, Speaking Positions', in Sobchak (ed.), The Persistence of History, p. 146. Further references are included within the text.

24. John Ellis quoted in Schwarz, p. 104

25. Thomas Elsaessser, 'Postmodernism as Mourning Work', Screen, vol. 42, no. 2, 2001, pp. 196-7.

26. Elsaesser, pp. 197-9.

27. Judith Butler, Precarious Life: The Powers of Mourning and Violence, London and New York, Verso, 2004, pp. xiv-xv. For an instance of the refusal to recognise colonial violence in Australian history as a grievable loss, see John Hirst, Sense and Nonsense in Australian History, Melbourne, Black Inc., 2005, pp. 80-103. Hirst draws a line between the 'compelling' case for an apology to the Stolen Generations and the 'hypocrisy' of the Australian nation apologising for British colonisation, pp. 90-1.

28. Elsaesser, pp. 198-9.

29. For an influential interpretation of Benjamin's allegorical thinking, see Susan Buck-Morss, The Dialectics of Seeing: Walter Benjamin and the Arcades Project, Cambridge, MA, The MIT Press, 1995 , pp. 159-201.

30. Walter Benjamin, The Origin of German Tragic Drama, trans. John Osbourne, NLB, London, 1977, p. 165 (first published as Ursprung des Deutschen Trauerspiels, Suhrkamp Verlag, Frankfurt am Main, 1963).

31. Benjamin, Origin of German Tragic Drama, pp. 177-8.

32. Walter Benjamin, 'Central Park', New German Critique, no. 34, 1985, p. 42. Further references are included within the text.
33. Benjamin's prolific writings on this theme since 1916 culminated in 'Theses on the Philosophy of History', completed in 1940 and first published in 1950. Reprinted in Walter Benjamin,

Illuminations, ed. Hannah Arendt, trans. Harry Zohn, Fontana Press, London, 1973, pp. 245-55.

34. See Ismail Xavier, Allegories of Underdevelopment: Aesthetics and Politics in Modern Brazilian Cinema, University of Minnesota Press, Minneapolis, 1997.

35. See Miriam Hansen, Babel and Babylon:

Spectatorship in American Silent Film, Harvard University Press, Cambridge, MA, 1991; Giuliana Bruno, Streetwalking on a Ruined Map, Princeton University Press, Princeton, NJ, 1993. For a recent auteurist engagement with cinematic allegory, see Michelle Langford, Allegorical Images: Tableau, Time and Gesture in the Cinema of Werner Schroeter, Intellect, Bristol, 2006.

36. Australian history films tend to be 'routine' in that, whatever their generic borrowings, they privilege a realist or naturalistic aesthetic over modernist self-reflexivity or postmodern fragmentation. This is not to deny elements of experimentation in the films, for instance the sung narrative in One Night the Moon and the transfixed moments of violence in freeze-frames of oil paintings in The Tracker, but the intention is allegorical rather than modernist or postmodern.

37. Craig Owens, 'The Allegorical Impulse: Toward a Theory of Postmodernism', in Scott Bryson, et al. (eds), Beyond Recognition: Representation, Power, and Culture, University of California Press, Berkeley, 1992, pp. 52-69 (first published in October, no. 12, 1980, pp. 67-86). Further references are included within the text.

38. Ismail Xavier, 'Historical Allegory', in Toby Miller and Robert Stam (eds), A Companion to Film Theory, Blackwell, Malden, MA, 1999, p. 346 Further references are included within the text.

39. Fredric Jameson, 'Third-World Literature in the Era of Multinational Capital', Social Text, no. 15 1986, pp. 65-88.

40. Benjamin's most famous allegorical image of history as catastrophe is found in Thesis IX which deploys Klee's 'Angelus Novus' as 'the angel of history' propelled into the future by a 'storm ... we call progress'. Benjamin, Illuminations, p. 249.

41. Xavier, p. 8

42. Historians have taken an interest in other films in the history cycle. See Jane Lydon, 'A Strange Time Machine: The Tracker, Black and White and RabbitProof Fence', Australian Historical Studies, vol. 35, no. 123, 2004, pp. 137-48.

43. Michael Fitzgerald, 'Black in the Outback: Translating the Western into Strine, director John Hillcoat mixes violence with surprising tenderness', Time International, South Pacific edn, New York, 17 October 2005, no. 41, p. 60. 
Fitzgerald goes on to say, 'the tracker played by David Gulpilil has his throat cut by ... tracker Two Bob (The Chant of Jimmie Blacksmith's Tom E. Lewis), in reprisal for a massacre. The idea came from Lewis himself [...] the director recalls, "he just pleaded with me, 'Can I kill David Gulpilil?' " This revision of Gulpilil's fate reverses the celebrity 'noble savage' image first allocated to Gulpilil by British director Nicholas Roeg in Walkabout (1971)

44. <http://www.bbc.co.uk/radio4/womanshour/ 02/2006_09_wed.shtml>

45. Shannon Harvey, 'Violent Outback Western a Ride into History', Sunday Times 9 0ctober 2005. Online.

46. Matt Coyte, Review, Australian Empire, 26 October 2005. Online.

47. Carol Hart, 'Portraits of Settler History in The Proposition', Senses of Cinema, no. 38, 2006. <http://www.sensesofcinema.com/contents/06/38/ propositions.html>

48. William D. Routt, 'The Evening of Redness in the West', The Age, Review, 1 October 2005, Talking Point, p. 8. Further references are included within the text.

49. This phrase was coined by Ross Gibson to describe the 'horror stretch' of Central Queensland. Ross Gibson, Seven Versions of an Australian Badland, University of Queensland Press, Brisbane, 2002, p. 1

50. Walter Benjamin, quoted in Susan Buck-Morss, The Dialectics of Seeing, p. 182

51. See Hart; and Martin Flanagan, 'Evil in Pictures', The Age, A2, 5 November 2005, p. 18.

52. For a Benjaminian concept of redemption, see Theses II and VI on 'weak' Messianic power and the possibility of past defeats being redeemed, or 'seized' by the present generation 'at a moment of danger'. Benjamin, Illuminations, pp. 246, 247.

53. For a searing account of the routine use of flogging against the lower ranks within Britain's armed forces at the time of first settlement in Australia, see Linda Colley, 'Another Making of the English Working Class: The Lash and the Imperial Soldiery', Socialist History Society, Occasional Papers Series, no. 17, 2003.

54. Benjamin, Origin of German Tragic Drama, p. 191 Benjamin goes on to say of 'the place of the chorus before the dramatic catastrophe', that 'even in its functional use allegory is not associated with the climax of the dramatic action, but it is an extended explanatory interlude', p. 192

55. Thank you to Kim Baston for listening to The Proposition and sharing her insights into how the landscape is formally realised in Nick Cave's songs and musical interludes. Cave has claimed on numerous occasions that he wrote the screenplay to accompany the soundtrack. In this sense the soundtrack exhibits a strong allegorical intention, creating the kind of 'explanatory interlude' that Benjamin saw as definitive of Baroque allegory.

56. The iconography of colonial violence,

reinterpreted in The Proposition, is preserved in the nation's archives not only in documents and photographs, but in scenes of flogging, spearing, shooting, hanging, burning, poisoning, rape and massacre in numerous feature films. Indigenous-settler violence as iconographic is evident in certain scenes from A Girl of the Bush (Franklyn Barrett, 1921), Bitter Springs (Ralph Smart, 1950), Journey Out of Darkness (James Trainor, 1967), Luke's Kingdom (Nine Network, Yorkshire Television, 1976), The Chant of Jimmie Blacksmith (Fred Schepisi, 1978), Rabbit-Proof Fence (Phillip Noyce, 2002), The Tracker (Rolf de Heer, 2002) and Black and White (Craig Lahiff, 2003).

57. Hart

58. Benjamin, 'Central Park', p. 38. Thank you to the anonymous referee who brought this quote to my attention, noting the correspondence between Elsaesser's use of Betroffenheit and Benjamin's, translated here as 'touched' rather than 'stung'.

59. Another such moment of laughter occurs in Rolf de Heer's film, The Tracker, adding an unexpected meaning to the iconography of Aboriginal men in neck chains. The laughter occurs between the fanatical white leader of the Native Police expedition (Gary Sweet) and David Gulpilil, the black tracker wearing a neck chain. Later in the film, the Tracker is freed from the neck chain which is then used to enchain the Fanatic. On the shock of such reversals see Collins and Davis, 'Disputing History', pp. 47-52.

60. Flanagan, p. 18

61. Gibson, pp. 53-80

62. North Australian, 27 April 1858, quoted in Gibson, p. 63

63. See Stuart Macintyre and Anna Clark, The History Wars, Melbourne University Press, Melbourne, 2003, pp. 43-4. Macintyre and Clark argue that colonial histories dealt with Aboriginal issues as a matter of policy to be debated with Whitehall, while twentieth-century national histories focused on economic and labour history, meaning that frontier violence disappeared from history until Charles Rowley and Henry Reynolds took it up again in the 1970s and 1980s.

64. In response to the US declaration of 'war on terror', Butler poses two ethical questions: 'whether ... the experiences of vulnerability and loss have to lead straightaway to military violence and retribution', and 'what, politically, might be made of grief besides a cry for war'. Butler, p. xii. 